\title{
The Impact of COVID-19: Become New Entrepreneurs with Online Business
}

\author{
Bima Yatna Anugerah Ramadhani \\ Alumni of International College, Faculty of Business Administration \\ Rajamangala University of Technology Krungthep, Bangkok 10120, Thailand. \\ Correspondent: b1ma.yatna@gmail.com
}

$\begin{array}{ll}\text { Received } & \text { : July 28, } 2021 \\ \text { Accepted } & \text { : August 25,2021 } \\ \text { Published } & \text { : October 31, } 2021\end{array}$

Citation: Ramadhani, B.Y.A. (2021). The Impact of COVID-19: Become New Entrepreneurs with Online Business. Ilomata International Journal of Management, 2(4), 293-299. https://doi.org/10.52728/ijim.v2i4.384

\begin{abstract}
The number of unemployed increased dramatically due to COVID-19. This can happen because many companies instruct their employees to work from home and some companies forced to do temporary dismissal and/or lay off their employees to survive during a pandemic. After that, many of people decide to create online business and become entrepreneurs. Products sold can be obtained from other people (be reseller) or make it by themselves. These products will be sold online, both with shopping applications and social media. The purpose of this research is to introduce the advantages of being an entrepreneur with online business and to show how technology affects the business. Therefore, this research tries to analyze the benefits of being an entrepreneur compared to being an employee and to find out how new entrepreneurs manage and market their products by technology during this pandemic. The samples of this research are 10 new entrepreneurs who get temporary dismissal of workers and or lay off from their company and open the online business in Surabaya and Sidoarjo. The methodology of this research is a qualitative methodology by analyzing social media accounts or online shop accounts that entrepreneurs use for selling their product and also conducting online interviews with them to ensure their accuracy. The results of this research indicate that online businesses provide benefits and convenience for entrepreneurs to do business during this pandemic and also give a motivation for entrepreneurs to continue and improve their business if COVID-19 has been completed.

Keywords: entrepreneurs, online business, layoffs, reseller
\end{abstract}

This is an open access article under the CC-BY 4.0 license.

\section{INTRODUCTION}

The COVID-19 outbreak was a pandemic that occurred everywhere. In developed and developing countries, the spread of this virus is very fast which results in many employees who have to be at home or work from home to break the chain of the COVID-19 virus, and also many people are 
becoming unemployed because they are laid off by the company. This dismissal is caused by the lack of income obtained by the company (Bai et al., 2021; Shafi et al., 2020).

The Ministry of Manpower (Kemnaker) noted the number of workers affected by layoffs (PHK) and the number of workers temporarily laid off due to the COVID-19 virus around 3.06 million people (CNN-Indonesia, 2020). The figure is data as of May 27, 2020. It is classified into several categories. (1) formal workers temporarily laid off, (2) formal workers affected by layoffs due to corona, (3) informal workers affected by corona, (4) formal and informal workers affected, (5) prospective Indonesian migrant workers, (6) repatriation of apprenticeships, (7) prospective Indonesian migrant workers, (8) incomplete data.

Table 1. Number of People Laid Off and Getting Temporary Dismissal

\begin{tabular}{lr}
\hline \multicolumn{1}{c}{ Category } & Number of People \\
\hline Formal workers temporarily laid off & $1,085,284$ \\
\hline Formal workers affected by layoffs due to corona & 380,221 \\
\hline Informal workers affected by corona & 318,959 \\
\hline Formal and informal workers affected & $1,757,464$ \\
\hline Prospective Indonesian migrant workers & 34,179 \\
\hline Repatriation of apprenticeships & 465 \\
\hline Prospective Indonesian migrant workers & 34,644 \\
\hline Incomplete data $\quad$ (Sources: CNN Indonesia) & $1,274,459$ \\
\hline \multicolumn{2}{c}{}
\end{tabular}

To survive during this pandemic, a lot of people try to open small businesses and become entrepreneurs (Susanti \& Widajatun, 2021). The product sold are also various kinds such as health equipment, food ingredients, food and so on (Nordhagen et al., 2021). The product can be obtained from other people (becoming a reseller) and produce it product by themselves (handmade). Handmade products are products that are made entirely with the support of hand tools or even mechanical devices and are done manually (Gaikwad \& Shiware, 2013). The number of tutorials for making a product on the internet makes many people compete to produce a product that is useful, has value, and has a selling power during a pandemic. Products must be unique and creative because the uniqueness and creativity have a positive effect on customer purchase intentions from handicraft products (Hsu \& Ngoc, 2016). The uniqueness and creativity can create an innovation that is useful to be a differentiator from other products and can also attract customers to buy products.

Business become easier because of technology. Technology is not only helping people to do things better and faster, but it can also create new ways to control, coordinate, and collaborate on activities more easily, at lower costs, governed by the law of diminishing costs (Cascio \& Montealegre, 2016). In this case, technology helps entrepreneurs to sell their product by online with social media and online shop application. If the entrepreneurs have a lot of products, they prefer to sell their products with an online shop application and promote their products through posts on Instagram so that the product can be known to the public and attract social media users to buy the product. However, if the products they sell are only a few (capacity is no more than 50 products), entrepreneurs prefer Instagram as a medium to sell and market their products.

During this pandemic, many people chose to become entrepreneurs. The entrepreneur is someone who creates and runs his own business (Dewi \& Mahendrawathi, 2019). An entrepreneur must dare to take risks such as the risk of investing money, time, and energy because running a business requires money and a long time (Mariotti, 2010). An entrepreneur must know the ethics of doing business, have good personal characteristics, and supporting skills in doing business. entrepreneurs must do business according to ethics because they must do business according to the law, do their jobs on time and place consumers and customers as 
priorities (Bulog \& Grančić, 2017). The application of skills in business can help develop entrepreneurs and to create potential opportunities for the future of their businesses (Sousa, 2018).

Business and the internet are a harmonious combination in this technological era because the internet can create faster interactions between all agents in the business world. The combination of the internet and business makes the term "online business". Online business is the business that using internet for the media interaction (Khan, 2016). In online business, there are several categories which include online purchasing, sales, production management, logistics, as well as internal communication and support services. The benefits of doing online business are increases revenue, reduces operation, maintenance, purchase, and procurement costs, build customer and supplier relationships, and improves the speed of the process of selling. However, doing the online business also have a lot of challenges that should an entrepreneur face. For the small businesses that use online method for the interaction, the big challenge is building trust with customer. The customer can trust the seller, if the seller can give what the customer wants. If the seller cannot give it, the customer will change his/her mind to buy the product from another store.

Layoffs are actions that often occur in organizations. The layoff is the company's action to suspend a worker (temporarily or permanently) for reasons other than the employee's actual performance (Mujtaba \& Senathip, 2020). During the pandemic of COVID-19, many companies were forced to lay off their workers. With reason, they wanted to reduce the expenses so the company can still run, increase profitability, and still achieve a competitive advantage (Maertz et al., 2010). Layoffs of workers are one of the ways that organizations use for reacting to changing environmental conditions $(\underline{\mathrm{Vu}, 2012})$.

A reseller is a person who applies the concept of "Buy-and-sell business" to his business. In this concept, a person buys a new product that is needed by everyone at a low price to be sold again at a profitable price (Piros \& Pinto, 2013). The profit is derived from the selling price of goods less the purchase price of the goods. However, the reseller is a person or businessman who remembers small and medium who resell products from suppliers to consumers (Jaouen \& Lasch, 2015).

\section{METHOD}

This study uses a qualitative methodology because this study seeks to understand the social reality that occurred during this pandemic by interviewing respondents (Bryman \& Bell, 2011). The respondents in this study were 10 entrepreneurs who had just started their business during the COVID-19 pandemic. With criteria, respondents are workers/employees who work from home or who get temporary dismissal workers or layoffs in Surabaya and Sidoarjo. After conducting interviews, this research also analyzed Instagram and Shopee accounts that were used by entrepreneurs to sell their products. The purpose is to find out a good way to market products with online media. And then, this research integrates the results of interviews and analysis with theories of entrepreneurship and online business from research conducted by others to ensure that this research has good results.

\section{RESULTS AND DISCUSSION}

Table 2. The Result of Interview

\begin{tabular}{l|l|l|l|l}
\hline Entrepreneurs & $\begin{array}{l}\text { Income before } \\
\text { COVID-19 }\end{array}$ & Kind of Product & Get Product from & $\begin{array}{l}\text { Profit per } \\
\text { Period of Sell }\end{array}$ \\
\hline 1 & Rp. 2,500,000 & $\begin{array}{l}\text { Homemade Masker, } \\
\text { Face Shield }\end{array}$ & Reseller & Rp. 1,750,000 \\
\hline 2 & Rp. 2,700,000 & Homemade Masker & Self-Production & Rp. 1,500,000 \\
\hline
\end{tabular}


The Impact of COVID-19: Become New Entrepreneurs with Online Business Ramadhani

\begin{tabular}{l|l|l|l|l}
\hline 3 & Rp. 3,000,000 & Instant Food & Reseller & Rp. 3,000,000 \\
\hline 4 & Rp. 4,500,000 & Snack & Self-Production & Rp. 4,100,000 \\
\hline 5 & Rp. 4,200,000 & Snack & Self-Production & Rp. 3,900,000 \\
\hline 6 & Rp. 3,500,000 & Homemade Masker & Self-Production & Rp. 2,000,000 \\
\hline 7 & Rp. 3,200,000 & Frozen Food & Reseller & Rp. 3,500,000 \\
\hline 8 & Rp. 3,400,000 & Hijab/veil & Reseller & Rp. 1,000,000 \\
\hline 9 & Rp. 2,200,000 & $\begin{array}{l}\text { Homemade Masker, } \\
\text { Hand Sanitizer }\end{array}$ & $\begin{array}{l}\text { Self-Production, } \\
\text { Reseller }\end{array}$ & Rp, 2,400,000 \\
\hline 10 & Rp. 5,000,000 & $\begin{array}{l}\text { Import Face Shield, } \\
\text { Masker }\end{array}$ & Reseller & Rp, 3,000,000 \\
\hline
\end{tabular}

Table 2 is the result of the first session of the interview. This session is an introduction to respondents who aim to find out what products are sold, where the products are obtained from, and the profit of each sale period. In table 2, it can be seen that respondents had different incomes before the COVID-19 pandemic. This shows that COVID-19 can affect any job. The benefits to employers differ depending on the goods they sell and the products they obtain. Entrepreneurs assume that if they want to have high profits, they must know what products are needed and are always wanted by many people. With modest capital to start a business, they must be able to obtain products that are cheap and have high selling power. As the concept of "Buy-and-Sell", to get high profits, an entrepreneur must get a new product at a low price and sell it at a high price (Piros \& Pinto, 2013). In table 2, it can be seen if the snack entrepreneurs get more profit than other vendors. This is because food is a recurring product. Repeated products are products that can be purchased repeatedly. It could be because the product provides an interesting experience when using the product.

In the second interview session, the researcher asked 4 questions to the 10 entrepreneurs as follows:

Question 1: What are the benefits of being an entrepreneur?

- Can determine their own income

- Flexible time, which is not bound by working hours

- Can enjoy work

- Increased insight into business and economics

- Has activities and work that can be done during COVID-19 Pandemic

- Increase income because some of their salary is reduced by a few percent.

The answer from the entrepreneurs can be concluded that being an entrepreneur has many features. Employers can have flexible time and can be used to work wherever and whenever (Marrioti, 2009). Being an entrepreneur with an online business during a pandemic is not a bad choice because entrepreneurs can work and manage their products from home. And for the delivery, they can give it to the delivery service.

Question 2: What are the obstacles when starting a business during the COVID pandemic?

All businesses have obstacles and competition. It is natural to find other sellers who sell the same product. So, the product sold must have uniqueness, creativity and an innovation in order to have a differentiator with other products ( $\mathrm{Hsu} \&$ Ngoc, 2016). Here are some of the obstacles that are often found by respondents when starting a business.

- Lack of confidence when starting a business.

- Many entrepreneurs sell the same product.

- There is competition in the price of the product being sold.

- the way to convince customers because a lot of customers feel worried if the product is not the same as their expectation.

- The income is not same as the previous salary at the first time. 
To be able to withstand the obstacles that often occur in business, there are several suggestions such as running a business in accordance with ethics, increasing business insight, having friends who know about business and developing the skills needed when doing business (Mariotti, 2010).

Question 3: How to start a business in a pandemic?

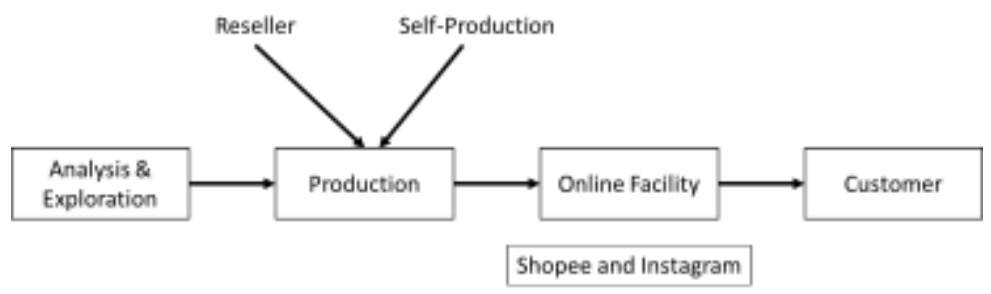

Figure 1.10 entrepreneurs almost have the same answer.

The essence of this answer is that before starting a business the entrepreneur must conduct exploration or analysis of what is needed by the community in the midst of this pandemic such as food, medical devices, and the need to entertain themselves while at home. Then, look for ways to get the products needed by the community, either by producing it yourself or buying it from other stores. Make sure the store sells products at a pretty cheap price. After getting the product, they upload pictures and product descriptions that will be sold on Instagram and Shopee in order to attract potential buyers.

Question 4: What are the benefits of doing business with Shopee and Instagram?

- Huge marketing range because it is online and anyone can the products

- Interesting images, videos and description to attract buyers

- Interact directly with buyers via "Direct Message" on Instagram and "Chat" on Shopee

- Shopee offers a "free shipping" voucher when the buyer makes a minimum purchase of Rp. 50,000 or Rp. 100,000. That can make customers buy some items again to get free shipping.

Table 3. The Analysis of Instagram and Shopee Account

\begin{tabular}{|c|c|c|c|c|c|c|c|c|c|c|c|}
\hline \multicolumn{2}{|l|}{ Indicator } & \multicolumn{10}{|c|}{ Entrepreneurs } \\
\hline & & 1 & 2 & 3 & 4 & 5 & 6 & 7 & 8 & 9 & 10 \\
\hline \multirow{2}{*}{ online facility } & Shopee & & & & & & & & & & \\
\hline & Instagram & & & & & & & & & & \\
\hline \multirow[t]{4}{*}{$\begin{array}{l}\text { How to } \\
\text { market }\end{array}$} & $\begin{array}{l}\text { Interactive } \\
\text { video }\end{array}$ & & & & & & & & & & \\
\hline & $\begin{array}{l}\text { Real Photo of } \\
\text { Product }\end{array}$ & & & & & & & & & & \\
\hline & $\begin{array}{l}\text { product } \\
\text { description }\end{array}$ & & & & & & & & & & \\
\hline & $\begin{array}{l}\text { Customer } \\
\text { Review }\end{array}$ & & & & & & & & & & \\
\hline
\end{tabular}

In Table 2.1, all entrepreneurs use Instagram accounts as a place to promote goods sold and there are 3 entrepreneurs who don't use Shopees. The products that sell by 3 people who only use Instagram as marketing media are homemade and frozen food entrepreneurs. Entrepreneurs 4, 5, and 7 argue if they are afraid to send their food if the place of the buyer is in another city far from their location. Shipping to other cities takes more than 1 day and it can make their products become stale before the customer gets the product. The three entrepreneurs assume that the 
number of products they sell is not too much. So, using Instagram is enough. Entrepreneurs who use Shopee accounts are entrepreneurs who sell products that do not have an expiration date or have a long enough expiry period and have a lot of products.

The ways to market their products by using Instagram and Shopee is same. By providing descriptions, photos, interactive videos (tutorial videos or videos that show the shape of the product), and also customer reviews. Product descriptions are useful to provide information to customers and provide education to customers so that customers know the truth of a product. The original photo of the product is useful for attracting customers to want to see the item description. While the video is useful to give an idea to the customer about the product. Customer reviews are useful as a sign of satisfaction if the products that entrepreneurs sell are the same as their expectations (Zhao et al., 2020).

\section{CONCLUSION}

The Pandemic COVID-19 caused an increase in unemployment in Indonesia. Many people lose their jobs and experience a reduction in their salary. In order to survive this pandemic, many people have decided to open and run small businesses online through shopping applications and social media. This research is to find out the advantages, obstacles, and ways to become entrepreneurs in the midst of a COVID-19 pandemic by using online facilities such as Instagram and Shopee. This research found that before becoming entrepreneurs, the prospective entrepreneurs must determine the products we will sell through analysis and exploration then find out where we can get the product. after that, we market through online facilities by displaying images, product descriptions, video, and customer reviews. The advantage of being an entrepreneur during COVID-19 is to have a job and extra income. However, there are some obstacles that must be known, such as many competitors who sell goods together with their own products, not much income because they are just starting a business and customers who still do not fully trust entrepreneurs. By using Instagram and Shopee, entrepreneurs can develop marketing areas and also interact directly with customers.

This study contains several limitations, which can be explored in future studies. The first is the limited reference obtained. second, the number of respondents is too small. And the last, questions being asked are too general and few. For further research, researchers will try to improve and increase the number of respondents and use qualitative methodology.

\section{REFERENCES}

Bai, C., Quayson, M., \& Sarkis, J. (2021). COVID-19 pandemic digitization lessons for sustainable development of micro-and small- enterprises. Sustainable Production and Consumption, 27, 1989-2001. https://doi.org/10.1016/j.spc.2021.04.035

Bryman, A., \& Bell, E. (2011). Business Research Methods (3rd ed.). Oxford University Press. https://www.worldcat.org/title/business-research-methods/oclc/746155102

Bulog, I., \& Grančić, I. (2017). The Benefits of Business Ethics - Ethical Behavior of Decision Makers: the Empirical Findings from Croatia. Mediterranean Journal of Social Sciences, 8(4), 914. https://doi.org/http://dx.doi.org/10.5901/mjss.2017.v8n4s1p9

Cascio, W. F., \& Montealegre, R. (2016). How Technology Is Changing Work and Organizations. Annual Review of Organizational Psychology and Organizational Behavior, 3(1), 349375. https://doi.org/10.1146/annurev-orgpsych-041015-062352

CNN-Indonesia. (2020). Pekerja Dirumabkan dan Kena PHK Akibat Corona Capai 3,05 Juta. CNN. https://www.cnnindonesia.com/ekonomi/20200720114203-92-526610/pekerjadirumahkan-dan-kena-phk-akibat-corona-capai-305-juta

Dewi, F., \& Mahendrawathi. (2019). Business Process Maturity Level of MSMEs in East Java, Indonesia. Procedia Computer Science, 161, 1098-1105. https://doi.org/10.1016/j.procs.2019.11.221 
Gaikwad, S. P., \& Shiware, T. A. (2013). Trends of Indian handicraft export since 2001. Global Management Review, 7(3), 38-44. https://t.ly/i8Th

Hsu, Y., \& Ngoc, A. N. (2016). The Handmade Effect: What is Special about Buying Handmade. International Review of Management and Business Research, 5(2), 594-609. https://irmbrjournal.com/papers/1466711111.pdf

Jaouen, A., \& Lasch, F. (2015). A new typology of micro-firm owner-managers. International Small Business Journal: Researching Entrepreneurship, 33(4), 397-421. https://doi.org/10.1177/0266242613498789

Khan, A. G. (2016). Electronic Commerce: A Study on Benefits and Challenges in an Emerging Economy. Global Journal of Management And Business Research, 16(1). https://journalofbusiness.org/index.php/GJMBR/article/view/1918

Maertz, C. P., Wiley, J. W., LeRouge, C., \& Campion, M. A. (2010). Downsizing Effects on Survivors: Layoffs, Offshoring, and Outsourcing. Industrial Relations: A Journal of Economy and Society, 49(2), 275-285. https://doi.org/10.1111/j.1468-232X.2009.00599.x

Mariotti, S. (2010). Entrepreneurship: Owning Your Future. Pearson Education Limited. https://www.pearson.com/us/higher-education/program/Mariotti-EntrepreneurshipOwning-Your-Future-High-School-Textbook-11th-

Edition/PGM157105.html?tab=resources

Mujtaba, B. G., \& Senathip, T. (2020). Layoffs and Downsizing Implications for the Leadership Role of Human Resources. Journal of Service Science and Management, 13(02), 209-228. https://doi.org/10.4236/jssm.2020.132014

Nordhagen, S., Igbeka, U., Rowlands, H., Shine, R. S., Heneghan, E., \& Tench, J. (2021). COVID-19 and small enterprises in the food supply chain: Early impacts and implications for longer-term food system resilience in low- and middle-income countries. World Development, 141, 105405. https://doi.org/10.1016/j.worlddev.2021.105405

Piros, C. D., \& Pinto, J. E. (2013). Economics for Investment Decision Makers: Micro, Macro, and International Economics. Wiley Publishing. https://www.wiley.com/enus $/$ Economics + for + Investment + Decision + Makers $\% 3 \mathrm{~A}+\mathrm{Micro} \% 2 \mathrm{C}+\mathrm{Macro} \% 2 \mathrm{C}+$ and $+\mathrm{I}$ nternational+Economics-p-9781118105368

Shafi, M., Liu, J., \& Ren, W. (2020). Impact of COVID-19 pandemic on micro, small, and medium-sized Enterprises operating in Pakistan. Research in Globalization, 2, 100018. https://doi.org/10.1016/j.resglo.2020.100018

Sousa, M. (2018). Entrepreneurship Skills Development in Higher Education Courses for Teams Leaders. Administrative Sciences, 8(2), 18. https://doi.org/10.3390/admsci8020018

Susanti, N., \& Widajatun, V. W. (2021). MSMEs Understanding of Taxation During the COVID-19 Pandemic. Journal of Innovation and Community Engagement, 2(1), 35-46. https://doi.org/10.28932/jice.v2i1.3689

$\mathrm{Vu}$, J. (2012). UK's Stock Market Reactions to Layoff Announcements. https://books.google.co.id/books?id=So_dnQEACAAJ\&printsec=copyright\&redir_esc $=\mathrm{y}$ $\# \mathrm{v}=$ onepage \&q\&f$=$ false

Zhao, Z., Wang, J., Sun, H., Liu, Y., Fan, Z., \& Xuan, F. (2020). What Factors Influence Online Product Sales? Online Reviews, Review System Curation, Online Promotional Marketing and Seller Guarantees Analysis. IEEE Access, 8, 3920-3931. https://doi.org/10.1109/ACCESS.2019.2963047 